\title{
Effect of Support on the Performance of CoMoRe Catalyst in Thiophene and Benzothiophene Hydrodesulfurization
}

\author{
RAMI DOUKEH ${ }^{1,2}$, MIHAELA BOMBOS ${ }^{2}$, DANIELA POPOVICl ${ }^{1}$, MINODORA PASARE ${ }^{3}$, ION BOLOCAN ${ }^{1 *}$ \\ 'Petroleum - Gas University of Ploiesti, 39 Bucuresti Blvd., 100520, Ploiesti, Romania \\ ${ }^{2}$ National Institute for Research Development for Chemistry and Petrochemistry- ICECHIM Bucuresti , 202 Splaiul Independetei, \\ 060021, Bucharest, Romania \\ ${ }^{3}$ Constantin Brancusi University of Targu Jiu, 30 Calea Eroilor, 210316, Targu Jiu, Romania
}

\begin{abstract}
This work is aimed at selection of a suitable support for CoMoRe catalyst in hydrodesulfurization (HDS) of thiophenes, $\gamma-\mathrm{Al} \mathrm{O}_{3}$ and $\gamma-\mathrm{Al} \mathrm{O}_{3}$-HMS were used as a support for CoMoRe catalyst with 4\%CO, 8\%Mo and $0.5 \%$ Re loading. The metal loading was incorporated by using the pore volume impregnation method, employing aqueous solutions of cobalt (II) nitrate, ammonium molibdate and rhenium (VII) oxide. The catalysts were sulfided with dimethyl disulphide at $250^{\circ} \mathrm{C}$ for $10 \mathrm{~h}$ and finally tested in the HDS reaction of thiophene and benzothiophene in different temperature and pressure conditions. The catalysts were characterized by determining the adsorption isotherms, the pore size distribution and the acid strengt, FTIR, $X R D$ and SEM. The catalyst supported on $\gamma-\mathrm{Al}_{2} \mathrm{O}_{3}$ displayed higher activity than catalyst supported on $\gamma-\mathrm{Al}_{2} \mathrm{O}_{3}-\mathrm{HMS}$. The results suggest that activity is favoured by the suitable textural and acidic properties of the support.
\end{abstract}

Keywords: hydrodesulfurization, catalyst, thiophenes

To minimize the negative effects of sulfur compounds on health and the environment, new strategies have been adopted worldwide to reduce sulfur emissions by imposing low sulfur concentrations in fuels. The desulfurization of refined petroleum products is usually accomplished by catalytic hydrodesulphurisation (HDS) processes in fixed bed reactors. Sulfur bonded to various organic species present in fuels is thus converted to $\mathrm{H}_{3} \mathrm{~S}$, which is eliminated and then converted to elemental sulfur through the Claus process. The concern for improving the performance of hydrodesulfurization catalysts is found in the large number of published papers that address this process [1-7].

In a recent paper [8], Gomez-Orozco studied the dibenzothiophene hydrodesulfurization reaction on NiMoW / SBA-15 type catalysts in the presence of Ti and without $\mathrm{Ti}$. The authors highlighted an increase in yield in hydrogenated products for the Ti-containing catalyst, termed CAT / 60TiS15. The superior activity for CAT / 60TiS15 and CAT / S15 was explained by the presence of a lower concentration of tetrahedral structures and by a higher dispersion of the Mo (W) S2 phase. The lower catalytic activity of the CAT / 40TiS15 catalyst could be due to the smaller specific surface area, pore volume and pore diameter. Hysteresis $\mathrm{H} 2$ type isotherms are also likely to affect the diffusion of the reactant / products in the pores. Despite the acidity associated with the catalyst structure and the formation of different types of acidic centers, it was observed that not only acidity affects the selectivity and catalytic activity but also the textural properties and superficial species have an important role in the catalytic activity of the NiMoW ternary catalyst deposited on the SBA- 15 and modified with varying amounts of Ti.

Dibenzothiophene hydrodesulfurization (HDS) and hydrodenitrification (HDN) of carbozole were studied in the presence of hydrogen $(P=55 \mathrm{bar})$ at $310^{\circ} \mathrm{C}$ in a batch reactor on NiMo / Al-HMS catalysts modified with phosphorus at various concentrations (0.5-2.0\% by weight) [9]. Based on the study, it was found that modifying the support with an optimized amount of P (1\%) decreased inhibition of the HDS reaction due to the presence of carbazole. Regardless of the studied reaction, all P- containing catalysts exhibited greater activity than those without P. The modified P-modified catalyst showed the best HDS activity and the lowest tendency to inhibit HDS simultaneously with HDN, activity that was close to that of a NiMo / $\mathrm{Al}, \mathrm{O}$ commercial catalyst sulfurized. This behavior was probably determined by the formation of irregular MoS structures having a high concentration on the marginal catalytic centers as well as the high concentration of Brønsted and Lewis acid centers. The decrease in catalyst activity when $P$ concentration increased to $2.0 \%$ by weight can be explained by an increase in the degree of polymerization of Mo species by Mo-0-Mo linkages. An increase in the concentration of Mo species resulted in harmful effects on the formation of the active phase during the sulphurization as well as on the dispersion of the active phase. José Escobar et al. [10] also prepared Ni-Mo/ alumina catalyst doped with $\mathrm{P}$, for hydrodesulfurization using sucrose as a reducing agent precursor.

Recently Obeso-Estrella et al. [11] prepared a series of CoMoW trimetallic catalysts deposited on $\mathrm{Al}_{2} \mathrm{O}_{3}-\mathrm{TiO}_{2}$ supportin order to study the effect of the partial substitution of Mo with $W$ on the performance of the catalyst in the dibenzothiophene (DBT) hydrodesulphurisation reaction. The study demonstrated that the partial substitution of Mo with W on the $\mathrm{CoMo} / \mathrm{Al}_{2} \mathrm{O}_{3}-\mathrm{TiO}_{2}$ catalyst leads to improved catalyst activity and density of acidic centers. Thus, the CoMoW catalyst containing $W$ at an atomic W / Mo ratio of 1.2 exhibited a catalytic activity of 2.5 times greater than that without $W$, and a higher hydrogenation selectivity than HDS for DBT conversion than the CoMo catalyst.

A non-supported cobalt and molybdenum sulfide type catalyst was prepared by Jacob Sollner [12] using ammonium heptamolibdate, cobalt nitrate and elemental sulfur under reflux in ammonium hydroxide. The synthesized catalyst was tested in the hydrodesulfurization process of dibenzothiophene at $350^{\circ} \mathrm{C}$. Studies have shown that a highly active CoMoS2 biphasic catalyst, composed of the $\mathrm{CO}_{9} \mathrm{~S}_{8}$ and $\mathrm{MOS}_{2}$ phases, has been obtained. It has also been shown that during the synthesis process a $\mathrm{CoMoO}_{4}$ type intermediate was obtained irrespective of whether the process resulted in the presence or absence 
of elemental sulfur. Probably the elemental sulfur acts as a supportfor precipitation of the $\mathrm{COMOO}_{4}$ intermediate. Thus, the elemental sulfur at $450{ }^{\circ} \mathrm{C}$ in the presence of $\mathrm{H}_{2}$ is converted to $\mathrm{H}_{2} \mathrm{~S}$ and determines the formation of the $\mathrm{Co}_{0} \mathrm{~S}_{8}$ and MoS, phases. The products obtained from the reaction indicate that the reaction takes place through a first stage of desulphurisation.

Morales-Ortuno et al. [13] prepared NiMo catalysts on titanium-containing SBA titans (Ti-SBA-15 and Ti-SBA-16) and titanium nanotubes with different pore diameters, which were tested in the hydrodesulfurization process of a diesel oil. It has been found that the $\mathrm{Ni}$ and Mo species are well dispersed in all Ti-containing catalytic supports. However, the TPR characterization showed that there were some differences in the characteristics of Mo species on Ti-SBA media and on nanotubular titanium supports. The above was mainly attributed to the differences in the chemical composition of the supports, which led to some differences in their acidity and the interactions between the metal supports. The Ti-SBA-15 and Ti-SBA-16 NiMo catalysts showed similar selectivity to the $\mathrm{NiMo} / \gamma-\mathrm{Al}_{2} \mathrm{O}_{3}$ catalyst. These catalysts have desulfurized $4,6-$ dimethyldibenzothiophene (DMDBT) by a first hydrogenation step. On the contrary, catalysts on titanium nanotubes have been able to achieve high conversion of 4,6-DMDBT by desulfurization not only by hydrogenation but also through the desulphurisation pathway.

Wang etal. [14] synthesized a mesoporous FDU-12 silica with a particular morphology, under low temperature conditions and by the addition of compounds with high acidity. The sulfurized NiMo / F-HP catalyst showed a high degree of dispersion and sulphurization that favored the increase in the content of active sites for HDT reactions of DBT.

Based on literature data analysis, it has been observed that catalytic support can contribute to improving the distribution of acidic centers and, implicitly, to increased concentration of acidic centers. In this study, the influence of the presence of mesoporous silica on Co-Mo-Re $/ \gamma-\mathrm{Al}_{2} \mathrm{O}_{3}$ catalyst activity was studied.

\section{Experimental part}

Catalyst preparation

The catalysts were prepared by simultaneous impregnation using the pore filling method. In summary, the cylindrical extrudates supports: $\gamma-\mathrm{Al}_{2} \mathrm{O}_{3}$ (surface area, pore volume) and $\gamma$-Al $\mathrm{O}_{3}$-HMS (40:60, surface area, pore volume) were impregnated with aqueous solutions of ammonium heptamolybdate $\left(\left(\mathrm{NH}_{4}\right) \mathrm{Mo}_{2} \mathrm{O}_{24^{\prime}}\right.$ Aldrich $99 \%)$, cobalt (II) nitrate hexahydrate $\left(\mathrm{Co}\left(\mathrm{NO}_{3}^{24}\right)_{2} \cdot 6 \mathrm{H}_{2} \mathrm{O}\right)$ and rhenium (VII) oxide $\left(\mathrm{Re}_{2} \mathrm{O}_{7}\right)$ and the resulting samples were subsequently dried for $4 \mathrm{~h}$ and at $120^{\circ} \mathrm{C}$ calcined at $450^{\circ} \mathrm{C}$ for $4 \mathrm{~h}$. The catalysts are denoted as CoMoRe $/ \gamma$ $\mathrm{Al}_{2} \mathrm{O}_{3}$ and $\mathrm{CoMoRe} / \gamma-\mathrm{Al}{ }_{2} \mathrm{O}_{3}-\mathrm{HMS}$ with the metal loading was $8 \% \mathrm{Mo}, 4 \% \mathrm{Co}$ and $0.5 \%$ Re.

\section{Catalysts characterization}

Temperature programmed desorption using diethyl amine as a probe molecule (DEA-TPD) was used to study the strength of acid sites available in catalysts. DEA-TPD experiments were performed using a DuPont Instrument Thermal Analyst 2000/2100 coupled to a module 951 Thermogravimetric Analizer. The catalysts structure and morphology was defined from textural characteristics (surface area, pore volume, average pore diameter, pore-size-distribution) and SEM analysis. Textural characteristics were determined by nitrogen adsorption at low temperature (77 K) on a Autosorb 1Quantacrome instrument. Scanning Electron Microscope FEl Inspect,
$S$ model was used to examine the morphology of the studied catalysts at an accelerating voltage from $200 \mathrm{~V}$ to $30 \mathrm{kV}$. X-ray diffraction was used to detect the presence and size of $\mathrm{Co}, \mathrm{Mo}$ and Re crystallites, confirmed by FTIR analysis. XRD patterns were recorded with a BRUKER D8 Advance X-ray pow der diffractometer, using CuK $\alpha$ radiation $(\lambda=0.154 \mathrm{~nm})$. Fourier transform infrared spectroscopy (FT-IR) was used to identify the functional groups of the catalysts using J asco 610 spectrometer (in an ATR mode), with a scanning range from 4000 to $550 \mathrm{~cm}^{\prime \prime}$ at a speed of $4 \mathrm{~cm}^{-1} \cdot \mathrm{s}^{-1}$ and with an average of 128 measurements in the final spectrum.

Catalysts reactivity in thiophenes hydrodesulphurization activity test

In this study the hydrodesulphurization of thiophene and benzothiophene on CoMoRe/ $\gamma-\mathrm{Al}_{2} \mathrm{O}_{3}$ and $\mathrm{CoMoRe} / \gamma-\mathrm{Al}_{2} \mathrm{O}_{3}$ HMS catalysts have been studied, at different temperatures from $200^{\circ} \mathrm{C}$ to $275^{\circ} \mathrm{C}$ and pressures from 30 bar to $60 \mathrm{bar}$, at $2 \mathrm{~h}^{-1}$ liquid hourly space velocity.

Oxidic catalyst samples have been activated with hydrogen, for two hours, at $250^{\circ} \mathrm{C}$ and 5 bar. After two hours, the temperature has been increased to $450^{\circ} \mathrm{C}$, and the activation continued for $6 \mathrm{~h}$. After activation, the catalysts have been sulphided for $8 \mathrm{~h}$, at $250^{\circ} \mathrm{C}$ and $5 \mathrm{bar}$, in a flow of $1 \mathrm{ml} / \mathrm{min}$ dimetyhldisulphide $1 \%$ in hexane.

The conversion of thiophenes was monitored by gas chromatography coupled with mass spectrometry. The activity data given are those obtained after $2 \mathrm{~h}$ on stream. The conversion of thiophene and benzothiophene have been calculated by reporting the amount of the converted reactant (thiophene or bezothiophene) to the amount of the reactant introduced in the reactor. The productyield resulted in hydrodesulfurization have been calculated by reporting the amount of reactant transformed in a product to the he amount of the reactant introduced in the reactor.

The catalytic tests have been performed in a standard fixed bed reactor, described in our previous work [1]. The feedstock consisted of $0.625 \mathrm{wt} \%$ thiophene (or 1 wt\% benzothiophene) solution in hexane, was used to simulate a FCC gasoline with a sulphur concentration of $2380 \mathrm{ppm}$. The feedstock was introduced by a metering pump and vaporized, mixed with hydrogen and preheated to a desired temperature before entering into the reactor. The hydrogen/thiophene (benzothiophene) molar ratio was 60:1. The influence of the support on hydrodesulfurization activity of CoMoRe catalyst was studied at differenttemperatures from $200^{\circ} \mathrm{C}$ to $275^{\circ} \mathrm{C}$ and pressures from 30 bar to 60 bar.

\section{Results and discutions}

\section{Catalysts characterization}

Thermal desorption curves of diethylamine for $\mathrm{CoMoRe}$ catalysts (on $\gamma-\mathrm{Al}_{2} \mathrm{O}_{3}$ and $\gamma-\mathrm{Al}_{2} \mathrm{O}_{3}$-HMS support) show that the catalytic centers are mainly weak acidic centers, before (A) and after sulphurization (B), as presented in figures 1 . After sulphurization, it was observed that the total concentration of acidic catalytic centers, deacresed for both catalysts $\mathrm{CoMoRe} / \gamma-\mathrm{Al}, \mathrm{O}_{3}$ and $\mathrm{CoMoRe} / \gamma-\mathrm{Al}, \mathrm{O}_{3}-\mathrm{HMS}$. For $\mathrm{CoMoRe} / \gamma-\mathrm{Al}_{2} \mathrm{O}_{3}$ the total concentration of acidic catalytic centers decreases from $0.731 \mathrm{meq} / \mathrm{g}$ to 0.685 $\mathrm{meq} / \mathrm{g}$ and from $0.884 \mathrm{meq} / \mathrm{g}$ to $0.655 \mathrm{meq} / \mathrm{g}$ for CoMoRe/ $\gamma-\mathrm{Al}_{2} \mathrm{O}_{3}-\mathrm{HMS}$. The acid strength distribution results, based on weak, medium and strong acidic centers are summarized in table 1.

After sulphurization, the acid strength of the catalysts should increase because $\mathrm{MoS}_{3}$ is strongly acidic than $\mathrm{MoO}_{3}$ [15], but in this case, the acidic strength after sulphurization 

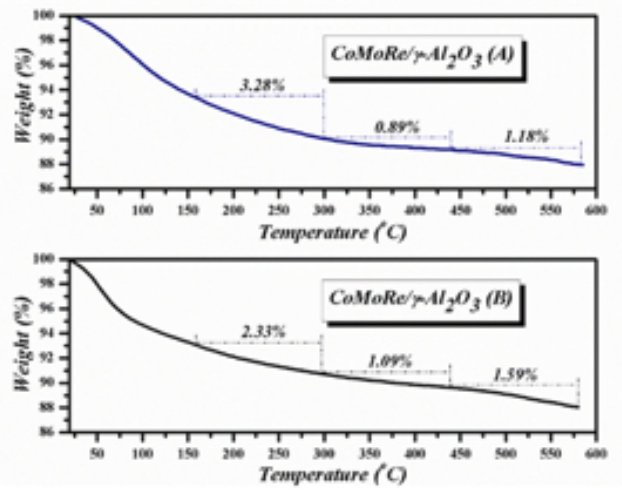
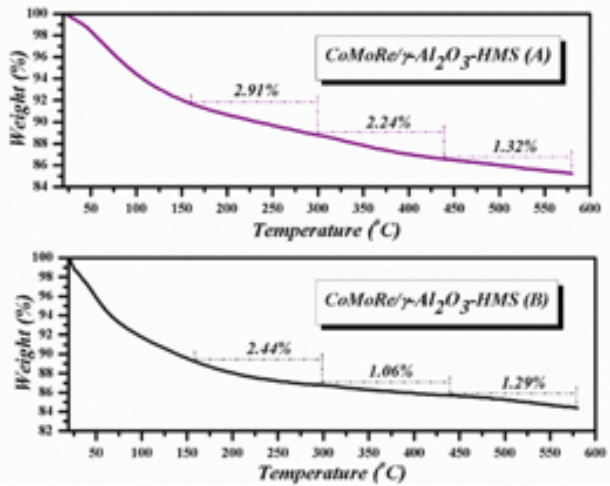

Flg. 1. Temperatureprogrammed desorption curves of diethylamine for catalysts before $(A)$

and after sulphurization (B)

Table 1

ACID STRENGTH DISTRIBUTION FOR COMORe $/ \gamma-\mathrm{Al}_{2} \mathrm{O}_{3}$ AND COMORe $/ \gamma-\mathrm{Al}_{2} \mathrm{O}_{3}$-HMS CATALALYSTS, BEFORE SULPHURIZATION(FRESH) AND AFTER SULPHURIZATION (SULPHIDED)

\begin{tabular}{|c|c|c|c|c|c|c|c|c|}
\hline \multirow{2}{*}{ Catalyst } & \multicolumn{2}{|c|}{$\begin{array}{c}\text { Weak acidic } \\
\text { centers meq/g }\end{array}$} & \multicolumn{2}{c|}{$\begin{array}{c}\text { Medium acidic centers } \\
\text { meq/g }\end{array}$} & \multicolumn{2}{c|}{$\begin{array}{c}\text { Strong acidic } \\
\text { centers meq/g }\end{array}$} & \multicolumn{2}{c|}{ Total acidity } \\
\cline { 2 - 10 } & fresh & sulphided & fresh & sulphided & fresh & sulphided & fresh & sulphided \\
\hline $\mathrm{CoMoRe} / \gamma-\mathrm{Al}_{2} \mathrm{O}_{3}$ & 0.448 & 0.319 & 0.122 & 0.149 & 0.161 & 0.217 & 0.731 & 0.685 \\
\hline $\mathrm{CoMoRe} / 7-\mathrm{Al}_{2} \mathrm{O}_{3}-\mathrm{HMS}$ & 0.398 & 0.334 & 0.306 & 0.145 & 0.180 & 0.176 & 0.884 & 0.655 \\
\hline
\end{tabular}

has decreased, as seen in table 1. This may be due to the low availability of diethylamine in the pores of the catalysts, as a result of specific area decrease, due to the clogging of the small pores.

The specific surface area, pore volume and average pore diameter were determined to obtain information on the diffusion rate of the reactants and reaction products into and out of the pores and the deposition of coke and other contaminants. The textural characteristics interrelated with the pores of the catalysts were determined by the adsorption and physical desorption of nitrogen by determining the moment when the surface is covered with a monolayer of gas molecules. The textural properties (BET surface area, pore volume and average pore diameter) of the catalysts are summarized in table 1. After sulphurization, the textural characteristics of the catalysts change by decreasing the specific surface, the pore volume and the average pore diameter. These changes are due to the replacement of oxygen from molybdenum oxide $\left(\mathrm{MoO}_{2}\right)$ with sulfur and the formation of molybdenum sulfide $\left(\mathrm{MoS}_{2}\right)$. The sulfur molecule is bigger than oxygen molecule so, $\mathrm{MoS}_{2}$ will have a higher volume than $\mathrm{MoO}_{2}$, reducing the pore dimensions.
The adsorption desorption isotherms and the pore-size distribution curves of $\mathrm{CoMoRe} / \gamma-\mathrm{Al}_{2} \mathrm{O}_{3}$ and $\mathrm{CoMoRe} / \gamma$ $\mathrm{Al}_{2} \mathrm{O}_{3}$-HMS catalysts, before sulphurization $(\mathrm{A})$ and after sulphurization (B), are presented in figure 2 .

CoMoRe $/ \gamma$-Al $\mathrm{O}_{3}$ catalyst exhibits a IV isotherm with a $\mathrm{H} 4$ hysteresis loop, characteristic for bottle neck pores. After sulphurization, the isotherm type and shape is the same, resulting only a decrease of the adsorbed volume (fig. 2). Similar pattern of behaviour is observed for CoMoRe/ $\gamma$-Al $\mathrm{O}_{3}$-HMS catalyst (fig. 2). The difference between the two catalysts is that CoMoRe/ $\gamma$-Al $\mathrm{O}_{3}$-HMS has wider pore volume than $\mathrm{CoMoRe} / \gamma-\mathrm{Al}_{2} \mathrm{O}_{3}$ so the nitrogen adsorbed volume is higher for CoMoRe/ $\gamma-\mathrm{Al}_{2} \mathrm{O}_{3}-\mathrm{HMS}$.

SEM analysis shows that there are differences between the shape and size of the catalysts particles. The SEM images for sulphided $\mathrm{CoMoRe} / \gamma-\mathrm{Al}_{2} \mathrm{O}_{3}$ and $\mathrm{CoMoRe} / \gamma-\mathrm{Al}_{2} \mathrm{O}_{-}-$ HMS catalysts are presented in figure 3. Figure $3 a$ ( 1000 magnification) shows the non-homogeneity of $\mathrm{CoMoRe} / \gamma$ $\mathrm{Al}_{2} \mathrm{O}_{3}$ catalyst and in figure $3 \mathrm{~b}$ (a higher magnification, $1500 \mathrm{x}$ ) different particle shapes can be observed elongated and conglomerates. The same can be observed for CoMoRe $/ \gamma-\mathrm{Al}_{2} \mathrm{O}_{3}-\mathrm{HMS}$ catalyst (fig. $3 \mathrm{c}, \mathrm{d}$ ).

Table 2

TEXTURAL PROPERTIES OF COMORe $/ \gamma$-Al $\mathrm{O}_{3}$ AND COMoRe $/ \gamma-\mathrm{Al}_{2} \mathrm{O}_{3}$-HMS CATALYSTS, BEFORE SULPHURIZATION ( FRESH) AND AFTER SULPHURIZATION (SULPHIDED)

\begin{tabular}{|c|c|c|c|c|c|c|}
\hline \multirow{2}{*}{ Catalyst } & \multicolumn{2}{|c|}{ SEET $\left(\mathrm{m}^{2} / \mathrm{g}\right)$} & \multicolumn{2}{c|}{$\begin{array}{c}\text { Pore volume } \\
\left(\mathrm{cm}^{3} / \mathrm{g}\right)\end{array}$} & \multicolumn{2}{c|}{$\begin{array}{c}\text { Average pore } \\
\text { diameter (nm) }\end{array}$} \\
\cline { 2 - 7 } & fresh & sulphided & fresh & sulphided & fresh & sulphided \\
\hline $\mathrm{CoMoRe} / \gamma-\mathrm{Al}_{2} \mathrm{O}_{3}$ & 180.33 & 145.67 & 0.294 & 0.247 & 3.42 & 3.31 \\
\hline $\mathrm{CoMoRe} / \gamma-\mathrm{Al}_{2} \mathrm{O}_{3}-\mathrm{HMS}$ & 273.50 & 211.69 & 0.419 & 0.332 & 3.63 & 3.46 \\
\hline
\end{tabular}
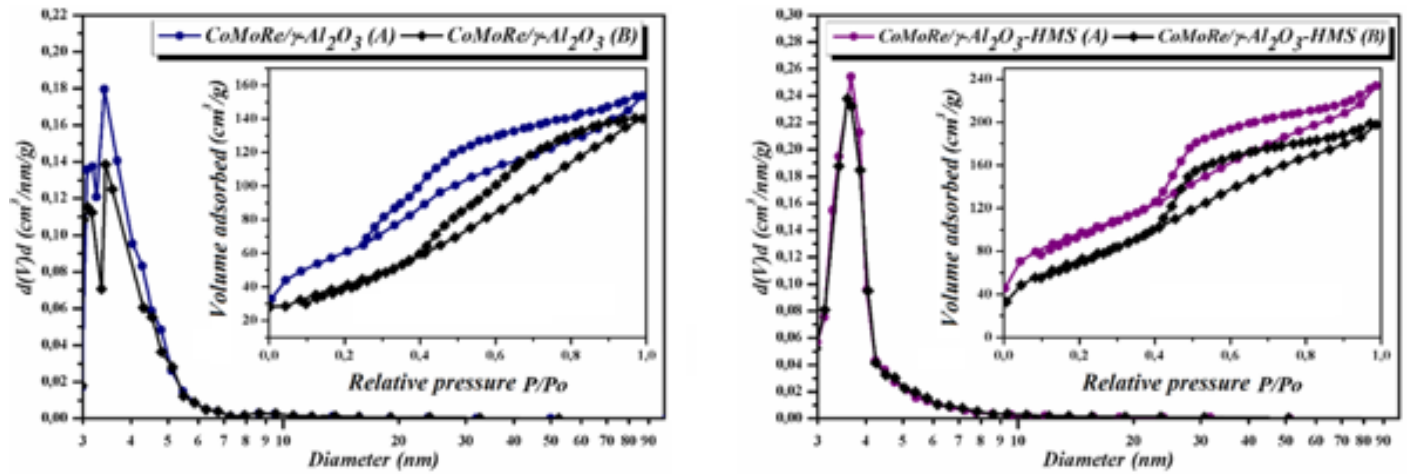

Fig. 2. Pore size distributions and adsorption desorption isotherm for catalysis before $(A)$ and after sulphurization (B) 

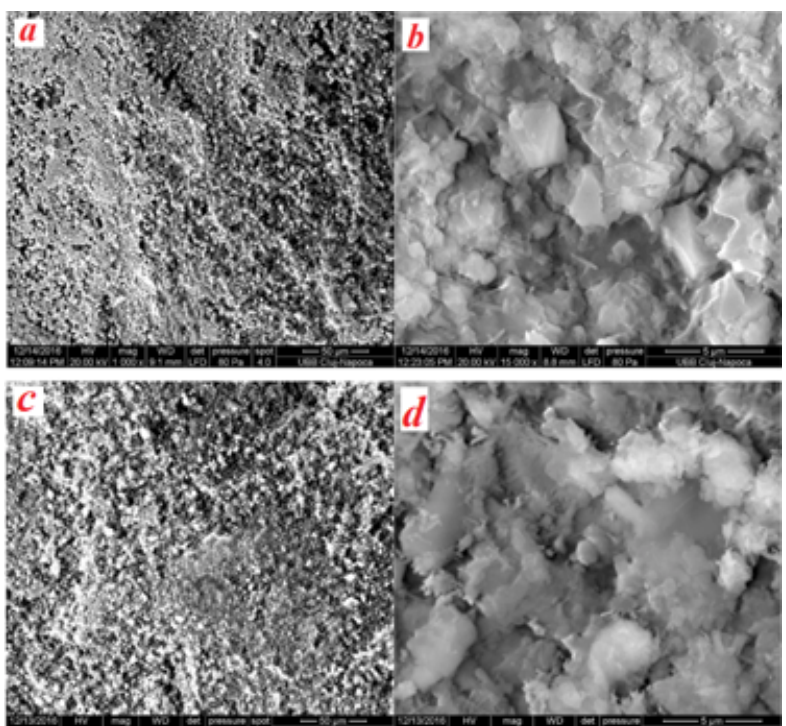

Fig. 3. SEM images for sulphided CoMoRe $/ \gamma-\mathrm{Al}_{2} \mathrm{O}_{3}(\mathrm{a}, \mathrm{b})$ and CoMoRe/ $\gamma-\mathrm{Al}_{2} \mathrm{O}_{3}$-HMS (c,d) catalyst

FTIR analysis of the catalysts was to identify functional groups on the prepared materials. The spectra were obtained with the ATR method, ranging from 4000 to 400 $\mathrm{cm}^{-1}$.

The IR spectra for the catalysts (fig. 4) show similar spectral bands at aprox. $3420 \mathrm{~cm}^{-1}$ and $1630 \mathrm{~cm}^{-1}$ corresponding to stretching and bending $\mathrm{O}-\mathrm{H}$ bonds vibrations, which can be attributed to the adsorbed water molecules [15]. The bands in the $500-750 \mathrm{~cm}^{-1}$ and 800 $\mathrm{cm}^{-1}$ regions are characteristic of the stretching vibrations of the $\mathrm{AlO} 6$ and $\mathrm{AlO} 4$ in the $-\mathrm{Al}_{2} \mathrm{O}_{3}$ support [16]. Between $500-1000 \mathrm{~cm}^{-1}$ are the characteristic bands for $\mathrm{Co}, \mathrm{Mo}$ and Re oxides. An exactly identification is imposible because of the bands overlaping. The Co-O stretching vibration is assigned between $500-590 \mathrm{~cm}^{-1}$, depending on cobalt oxidation number. $\mathrm{CoOH}$ shows spectral band at $585 \mathrm{~cm}^{-1}$, $\mathrm{CoO}$ at $505 \mathrm{~cm}^{-1}$, and $\mathrm{Co}_{3} \mathrm{O}_{\text {at }} 570 \mathrm{~cm}^{-1}$ [17]. FTIR spectra of $\mathrm{CoMoRe} / \mathrm{gr}-\mathrm{Al}_{2} \mathrm{O}_{3}-\mathrm{HMS}$ catalyst (fig. 4), in the range of
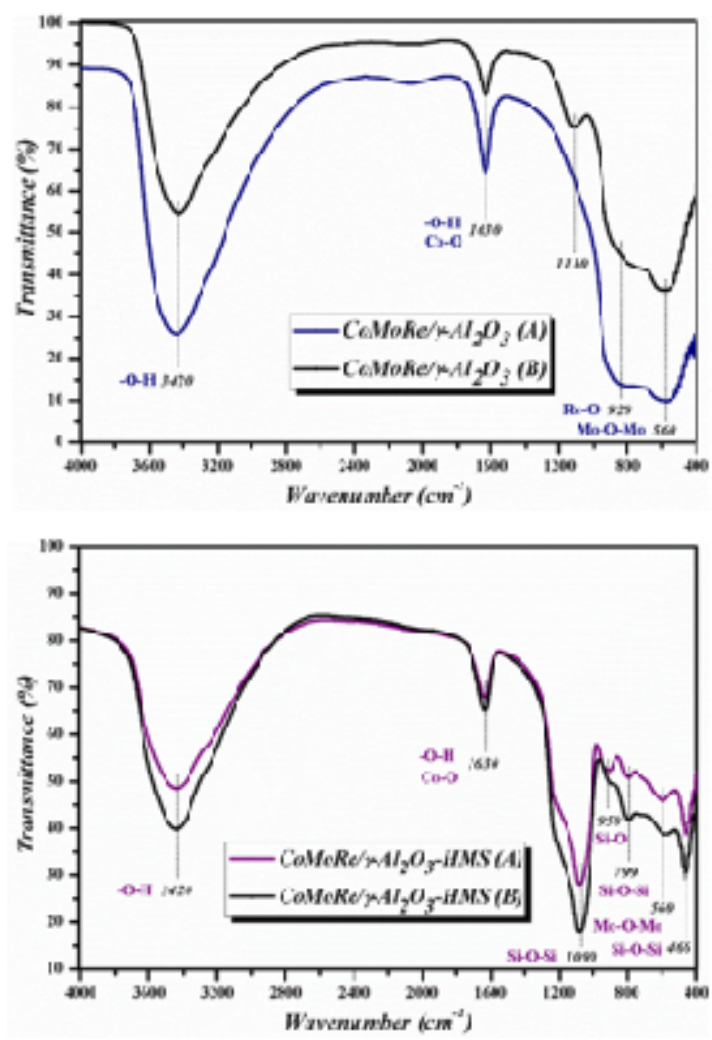

Fig. 4. FTIR spectra for catalysts, before (A) and after sulphurization (B)
$500 \mathrm{~cm}^{-1}$ and $1000 \mathrm{~cm}^{-1}$, show specific customized spectral bands from silica, due to Si-O-Si bonds [18].

Figure 5 shows the X-ray diffractogram of the catalyst before and after the sulfurization. Both catalysts prior to sulfurization exhibit intense XRD peaks at $2 \theta \sim 36.7^{\circ} ; 45.5^{\circ}$ and $66.8^{\circ}$ which are specific for $\gamma-\mathrm{Al}_{3} \mathrm{O}_{3}$ support. ReO has assigned specific peaks at $2 \theta \sim 38^{\circ}, 40^{\circ}, 42.8^{\circ}, 44^{\circ}$ and $65^{\circ}$. HMS shows specific peaks in the region $2 \theta \sim 20-30^{\circ}$ which corresponds to the amorphous state of HMS [1920].
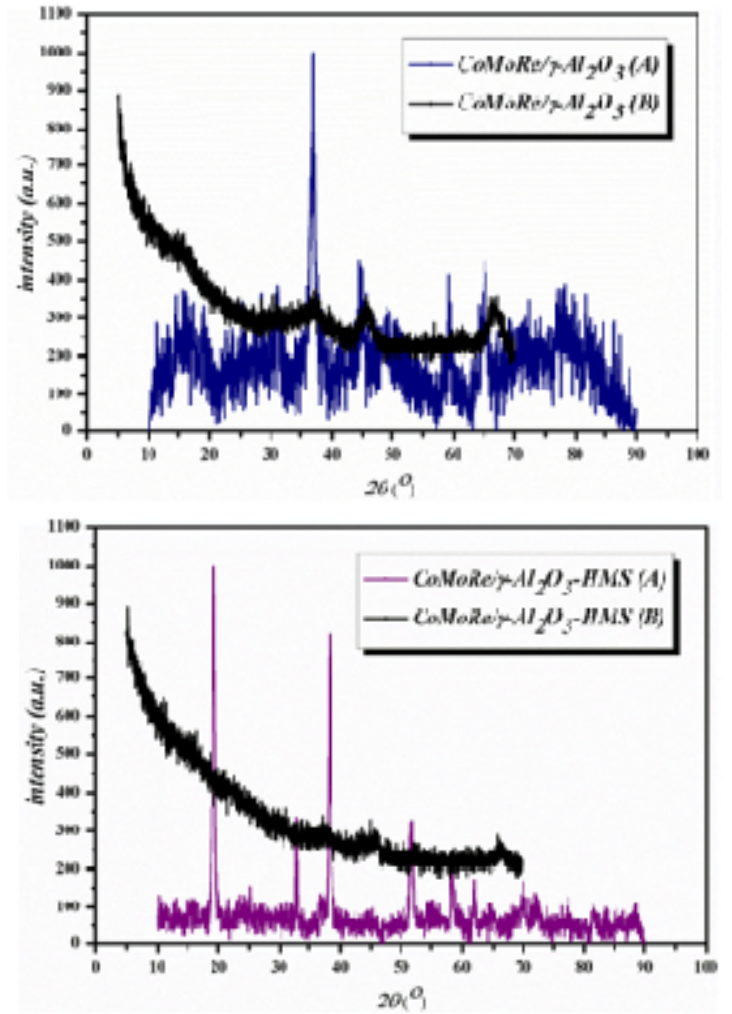

Fig. 5. XRD spectra for catalysts, before (A) and after sulphurization (B)

The catalysts have undergone structural changes after sulfurization, either by decreasing the peak intensity or by dropping the specific peaks, indicating that the present species has been amorphous, or crystallites are too small to record a RX signal.

\section{Catalysts hydrodesulphurization activity}

a. Effect of reaction temperature

Studies of thiophene and benzothiophene conversion as a function of temperature are presented in Figure 6 and the results show that the activity of both catalysts increased with the temperature. The hydrodesulfurization of thiophene and benzothiophene on CoMoRe $/ \gamma-\mathrm{Al}_{2} \mathrm{O}_{3}$ and $\mathrm{CoMoRe} / \gamma-\mathrm{Al}_{2} \mathrm{O}_{3}-\mathrm{HMS}$, proved to be efficiently in the range of $200^{\circ} \mathrm{C}-275^{\circ} \mathrm{C}$, at 30 bar and LHSV of $2 \mathrm{~h}^{-1}$.

Thiophene conversion with temperature, follows a similar slope for both catalysts, between $200-225^{\circ} \mathrm{C}$, but is higher by about $20 \%$ over CoMoRe/g-Al $\mathrm{O}_{3}$. At higher temperatures of $275^{\circ} \mathrm{C}$, thiophene is converted more than $99 \%$ over both catalysts. On CoMoRe $/ \gamma-\mathrm{Al}_{2} \mathrm{O}_{3}$ catalyst, thiophene conversion increased from $54.54 \%$ (at $200^{\circ} \mathrm{C}$ ) to $85 \%$ at $225^{\circ} \mathrm{C}$ and reached almost $100 \%$ at $275^{\circ} \mathrm{C}$. On $\mathrm{CoMoRe} / \gamma-\mathrm{Al}_{2} \mathrm{O}_{3}$-HMS, thiophene conversion was $35 \%$ at $200^{\circ} \mathrm{C}$ but also reached almost $100 \%$ at $275^{\circ} \mathrm{C}$.

Benzothiophene conversion was higher than thiophene conversion on both catalysts, due to the lower aromatic character of benzothiophene which means a higher activity. At $200^{\circ} \mathrm{C}$, benzothiophene conversion on CoMoRe/ 

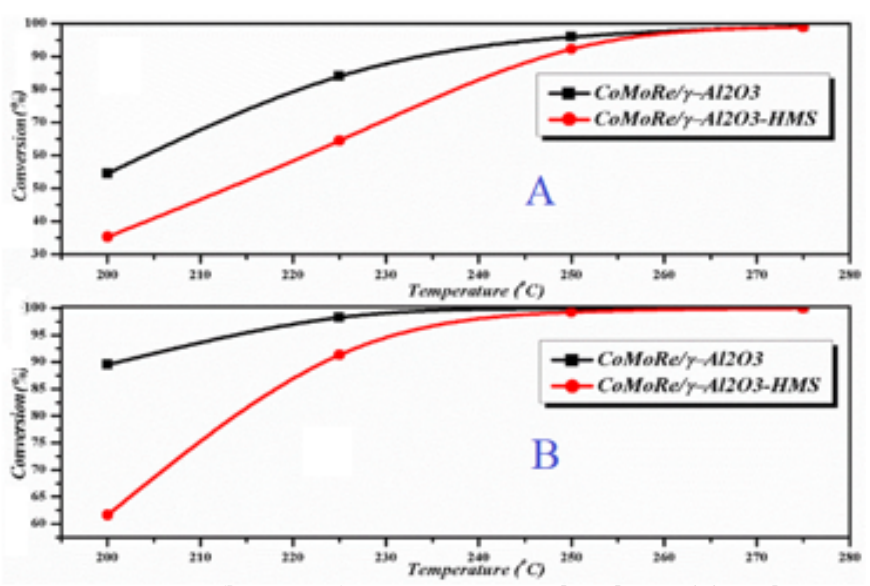

Fig. 6. Influence of temperature on thiophene $(A)$ and benzothiophene $(\mathrm{B})$ conversion at $30 \mathrm{bar}$ and LHSV $=2 \mathrm{~h}^{-1}$
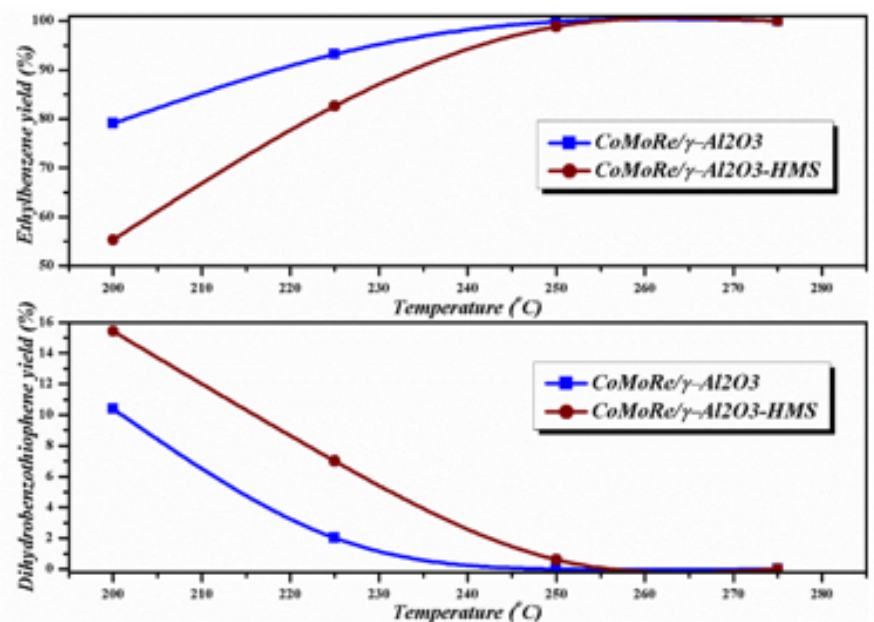

Fig. 7. Influence of temperature on products yield in benzothiophene hydrodesulphurization at 30 bar and LHSV $=2 \mathrm{~h}^{-1}$

$\gamma-\mathrm{Al}_{2} \mathrm{O}_{3}-\mathrm{HMS}$ is $60 \%$ and on CoMoRe $/ \gamma-\mathrm{Al}_{2} \mathrm{O}_{3}$ is almost $90 \%$. Over $250^{\circ} \mathrm{C}$, the conversion is $100 \%$.

It is noted that for the CoMoRe catalyst, the introduction of mesoporous silica into the $\gamma-\mathrm{Al}_{2} \mathrm{O}_{3}$ support decreased the conversions of thiophene and benzothiopnene compared to the $\gamma-\mathrm{Al}_{2} \mathrm{O}_{3}$ support. How ever, smaller conversions are only at temperatures from 200 to $250{ }^{\circ} \mathrm{C}$. At $275^{\circ} \mathrm{C}$, the conversions reached almost $100 \%$ for CoMoRe supported on both $\gamma$-Al $\mathrm{O}_{3}$ and $\gamma$ - $\mathrm{Al}_{2} \mathrm{O}_{3}$ - $\mathrm{HMS}$.

The tests performed in this work, over CoMoRe catalyst, suggested that benzothiophene is first hydrogenated to dihydro-benzothiopene (DHBT), then hydrodesulfurized to ethylbenzene (EB). Thiophene is first hydrodesulfurized to butadiene and further hydrogenated to butane.

In benzothiophene hydrodesulphurization, the variation of reaction products yields with temperature is represented in figure 7. It is observed that the intermediary reaction product DHBT, is completely converted with the temperature increase from 200 to $275^{\circ} \mathrm{C}$, meanwhile, the yield of the final product, ethylbenzene, increases.

\section{b. Effect of reaction pressure}

The influence of pressure on hydrodesulphurization process of thiophene and benzothiophene on the CoMoRe catalysts on both supports were studied in the range of 3060 bar at $200^{\circ} \mathrm{C}$ and $2 \mathrm{~h}^{-1}$ liquid hourly space velocity.

The reaction pressure has small influence on the hydrodesulfurization process of thiophene and benzothiophene, on both catalysts studied: CoMoRe $/ \gamma$ $\mathrm{Al}_{2} \mathrm{O}_{3}$ and $\mathrm{CoMoRe} / \gamma-\mathrm{Al}_{2} \mathrm{O}_{3}$-HMS (fig. 8). On CoMoRe $/ \gamma$ -
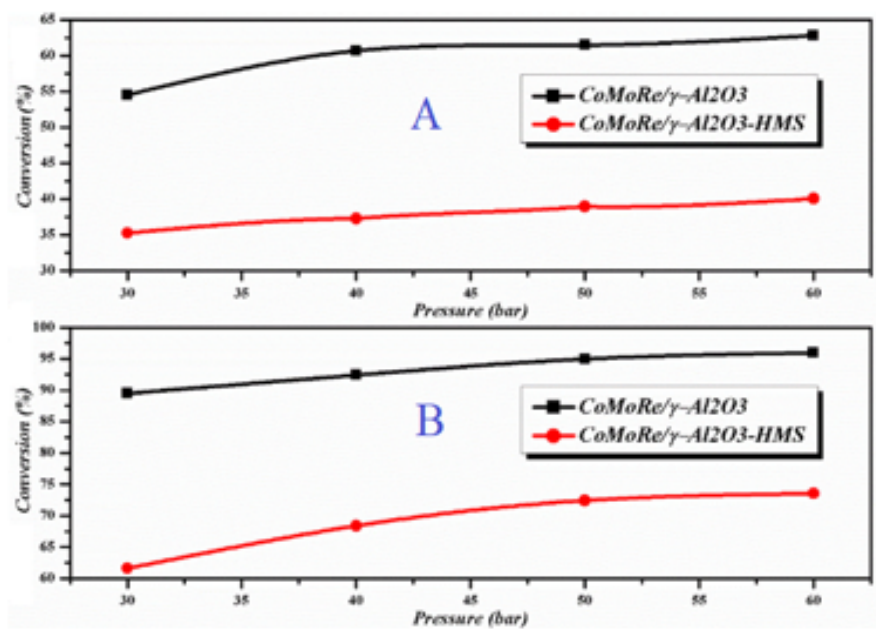

Fig. 8. Influence of pressure on thiophene and benzothiopene conversion at $200^{\circ} \mathrm{C}$ and LHSV $=2 \mathrm{~h}^{-1}$
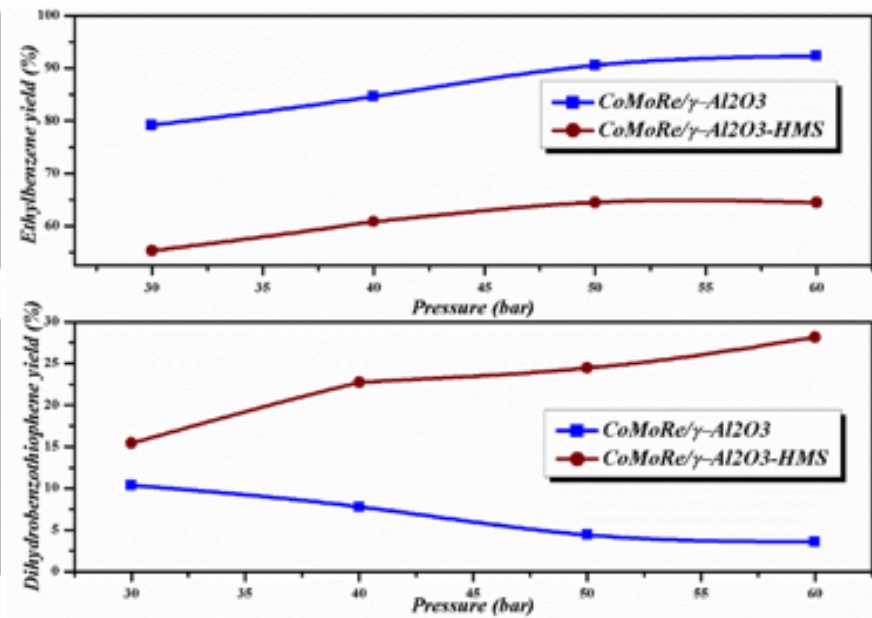

Fig. 9. Influence of pressure on hydrodesulphurization products yield at $200^{\circ} \mathrm{C}$ and LHSV $=2 \mathrm{~h}^{-1}$

$\mathrm{Al}_{2} \mathrm{O}_{3}$, at $200^{\circ} \mathrm{C}$ and $\mathrm{LHSV}$ of $2 \mathrm{~h}^{-1}$, the conversion of thiophene increases from $54.54 \%$ to $62.80 \%$ ( only by $8.14 \%$ ), when pressure increases from $30 \mathrm{bar}$ to $60 \mathrm{bar}$. On CoMoRe/ $\gamma$ $\mathrm{Al}_{2} \mathrm{O}_{3}$-HMS catalyst, thiophene conversion increment is only by $5 \%$, from $35 \%$ to $40 \%$. This may be attributed to larger pores of $\mathrm{CoMoRe} / \gamma-\mathrm{Al}_{2} \mathrm{O}_{3}$-HMS catalyst.

The benzothiophene conversion increases from 89.49 $\%$ (30 bar) to $95.96 \%$ (60 bar), on CoMoRe $/ \gamma-\mathrm{Al}_{2} \mathrm{O}_{3}$ catalyst and from $60 \%$ (30 bar) to $75 \%$ (60 bar), on CoMoRe $/ \gamma-\mathrm{Al}_{2} \mathrm{O}_{3}$ HMS catalyst. We note that the more active in the hydrodesulfurization reaction the CoMoRe catalyst is, the weaker is the pressure influence on thiophene and benzothiophene conversion.

Figure 9 shows the variation of products yields with pressure. An increase in pressure from 30 bar to $60 \mathrm{bar}$, favors the formation of final products in the case of benzothiophene hydrodesulfurization. On CoMoRe $/ \gamma-\mathrm{Al}_{2} \mathrm{O}_{3^{\prime}}$ the yield in ethylbenzene at 30 bar is $79.19 \%$ and in $2,3^{\prime}$ dihydrobenzothiophene is $10.38 \%$. At $60 \mathrm{bar}$, the yield in ethylbenzene increases to $92.38 \%$ and in 2,3-dihydrobenzothiophene decreases to $3.58 \%$.

On CoMoRe $/ \gamma-\mathrm{Al}_{2} \mathrm{O}_{3}$-HMS catalyst, the yield in the intermediate product, 2,3-dihydrobenzothiophene, increases with pressure, from $15 \%$ (30 bar) to $27 \%$ (60 bar), and so the final product does. The yield in ethylbenzene increase from 55 to $65 \%$, with the pressure increase from 30 bar to 60 bar.

\section{Conclusions}

The CoMore catalyst deposited on the $\mathrm{Al}_{2} \mathrm{O}_{3}$ and $\mathrm{Al}_{2} \mathrm{O}_{3}$ HMS supports was prepared simultaneous impregnation 
using the pore filling method. The catalysts have been characterized to determine: the textural characteristics, the chemical and the structural properties. The presence of HMS mesoporous silica causes a decrease in CoMoRe/ $\gamma-\mathrm{Al}_{2} \mathrm{O}_{3}$ catalyst acidity and increases the textural features. On the other hand the textural features of both catalysts decrease after sulfurization, due to the larger volume of the sulfur atoms compared to the oxygen that it has replaced.

The influence of pressure and temperature on the performance of the HDS process is basically similar on the two catalysts. The presence of HMS type mesoporous silica reduces the performance of the $\mathrm{CoMoRe} / \gamma-\mathrm{Al}_{2} \mathrm{O}_{3}$ catalyst probably due to the negative influence on the concentration of acidic centers sau HMS structure and catalyst-support interaction.

\section{References}

1. DOUKEH, R., BOMBOS, M., TRIFOI, A., MIHAI, O., POPOVICI, D., BOLOCAN, I., BOMBOS, D., Comptes Rendus Chimie, 21, no.3-4, 2018, p. 277-287.

2. Al-ZAQRI, N., ALSALME, A., ADIL, S. F., ALSALEH, A., ALSHAMMARI, S. G., ALRESAYES, S. I., ALOTAIBI, R., AL-KINANY, M., SIDDIQUI, M. R. H., J ournal of Saudi Chemical Society, 21, 2017, p. 965-973.

3. DOUKEH, R., TRIFOI, A., BOMBOS, M., BANU, I., PASARE, M., BOLOCAN, I., Rev.Chim. (Bucharest), 69 , no. 2, 2018, p. 396-399.

4. BOUKOBERINE, Y., HAMADA, B., Arabian J ournal of Chemistry, 9 , 2016, p. S522-S527.

5. DOUKEH, R., BOMBOS, M., MOLDOVAN, M., BOLOCAN, I., Rev.Chim.(Bucharest), 69, no. 6, 2018, p. 1386-1390.

6. WANG, H., LIU, S., GOVINDARAJ AN, R., SMITH, K. J., Applied Catalysis A: General, 539, 2017, p.114-127.

7. DOUKEH, R, BOMBOS, M, TRIFOI, A, PASARE, M, BANU, I, BOLOCAN, I, Rev. Chim. (Bucharest), 68, no.7, 2017, p. 1496-1500.
8. GOMEZ-OROZCO, S.Y., HUIRACHE-ACUNA, R., PAWELEC, B., FIERRO, J.L.G., RIVERA-MUNOZ, E.M., LARA-ROMERO, J., ALONSONUNEZ, G., Catalysis Today, 305, 2018, p 152-161

9. ZEPEDA, T.A., PAWELEC, B., OBESO-ESTRELLA, R., DIAZ DE LEON, J.N., FUENTES, S., ALONSO-NUNEZ, G., FIERRO, J.L.G., Applied Catalysis B, 238, 2018, p 147-160

10. ESCOBAR, J., BARRERA, M. C., GUTIERREZ, A. W., CORTESJACOME, M. A., ANGELES-CHAVEZ, C., TOLEDO, J. A., SOLIS-CASADOS, D.A., Applied Catalysis B: Environmental 237, 2018, p.708-720.

11. OBESO-ESTRELLA, R., FIERROB, J.L.G., DIAZ DE LEONA, J.N., FUENTESA, S., ALONSO-NUNEZA, G., LUGO-MEDINAC, PAWELECB, E., B., ZEPEDA, T.A., Fuel, 233, 2018, p.644-657.

12. SOLLNER , J., GONZALEZ , D.F., LEAL, J.H., EUBANKS, T.M., PARSONS, J.G., Inorganica Chimica Acta, 466, 2017, p.212-218.

13. J. ARTURO MENDOZA-NIETO, FERNANDO ROBLES-MENDEZ, TATIANA E. KLIMOVA, Catalysis Today, 250, 15 July 2015, p 47-59.

14. WANG, X., DU, P., CHIB, K., DUAN, A., XU, C., ZHAO,Z., CHEN, Z, ZHANG, H.,Catalysis Today, 291, August 2017, p 146-152.

15. AL-HAMMADI, S.A., A.M. AL-AMER, SALEH, T.A., Chemical Engineering J ournal, 345, 2018,p. 242-251.

16. MASOUMEH TABATABAEE, N.S., International Journal of BioInorganic Hybrid Nanomaterials, 1(4), 2012.p. 253-256.

17. TANG, C. W., WANG, C.B., CHIEN, S.H., Thermochimica Acta, 473(1), 2008,p. 68-73.

18. PALCHEVA, R KALUZA, L, DIMITROV, L, TYULIEV, G, AVDEEV, G, JIRATOVA, K, SPOJ AKINA, A, Applied Catalysis A: General, 520,2016,p. 24-34.

19. ALIBOURI, M., S.M. GHOREISHI, AGHABOZORG, H.R., Journal of Supercritical Fluids, 49(2), 2009, p. 239-248.

20. WHELAN, J.; KATSIOTIS, M. S.; STEPHEN, S.; LUCKACHAN, G. E.; THARALEKSHMY, A.; BANU, N.-D.; IDROBO, J.-C.; PANTELIDES, S. T.; VLADEA, R. V.; BANU, I.; ALHASSAN, S. M, Energy \& Fuels 2018, 32, $7820 " 7826$.

Manuscript received: 20.11 .2018 